\title{
10. Lessons from Gurgaon, India's private city
}

\author{
Shruti Rajagopalan and Alexander Tabarrok
}

\section{NEW CITIES FOR AN URBAN WORLD}

The world's urban population quadrupled between 1950 and 2000. By 2050, it will have doubled again. Total population and the rate of urbanization are both increasing faster in the developing than in the developed world. In India, for example, the urban population will triple between 2000 and 2050. Between 2015 and 2030, urban populations in India will increase by 268 million. ${ }^{1}$ The McKinsey Global Institute (2010) estimates that such an expansion will require over a trillion US dollars in capital investment including 700 to 900 million square metres of new commercial and residential space every year - on the order of a new Chicago - and 2.5 billion square metres of roads as well as 7,400 kilometres of metros and subways.

The problem with these numbers is not the expense required for expansion. Increases in the overall population and in the urban population (where productivity is higher than in rural regions) as well as improvements in national productivity will likely generate more than enough wealth to support the expansion. The problem is political and organizational. Many currently less-developed countries, including India, remain high in corruption and low in efficiency, especially in the administration of their towns and cities.

Wise and forward-thinking political institutions and actors can greatly reduce the cost of the urban transition by planning and reserving, in advance of development, space for future streets, sewage, electricity (underground access), and parks. With advance notice of where sewage and other access points will be placed, private developers can plan to link to main sewage lines even in advance of their provision. Unfortunately, the developing nations where much of the urban growth will occur do not have a successful history of advance planning. Indeed, foresighted, capable, independent, and uncorrupted bureaucracies are rare everywhere.

We may hope that foresighted and public-spirited government bureaucracies and planners will provide India and other developing nations with 
wise urban planning. India and other developing nations, however, will need to build the equivalent of hundreds of new cities and megacities over the next few decades. ${ }^{2}$ It seems unwise to rely on what has historically been rare for this massive transformation. Is there an alternative? In this chapter, we explore to what extent private urban planning may substitute for government planning.

We use Gurgaon, India, as a case study for the failure of the state to provide essential public goods and urban planning and the extent to which the private sector can take over such provisioning. In Gurgaon, the private sector has filled many gaps left by the failure of the state. Nevertheless, some gaps have been too large for the private sector to bridge.

\section{INTRODUCTION TO GURGAON}

Gurgaon is a district in the state of Haryana located just to the southwest of Delhi (see Figure 10.1). Gurgaon was little more than a village in 1979, when it was split administratively from the more populous and developed area of Faridabad in Haryana. At the time, Faridabad had access to transport and public utilities and was a strong industrial city

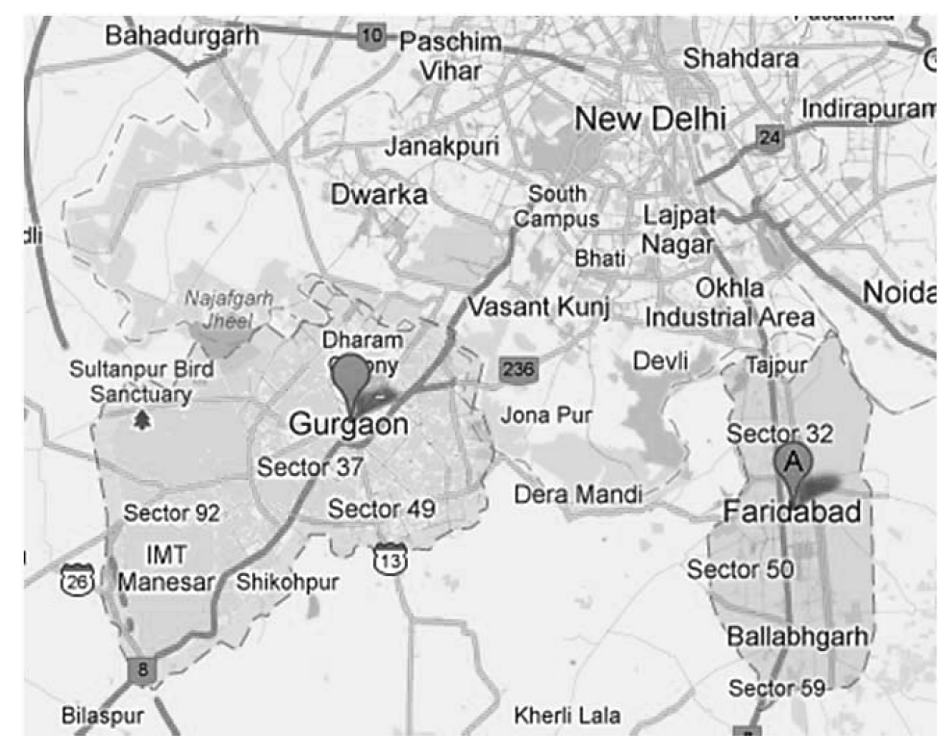

Source: Google Maps

Figure 10.1 Gurgaon and Faridabad Districts 


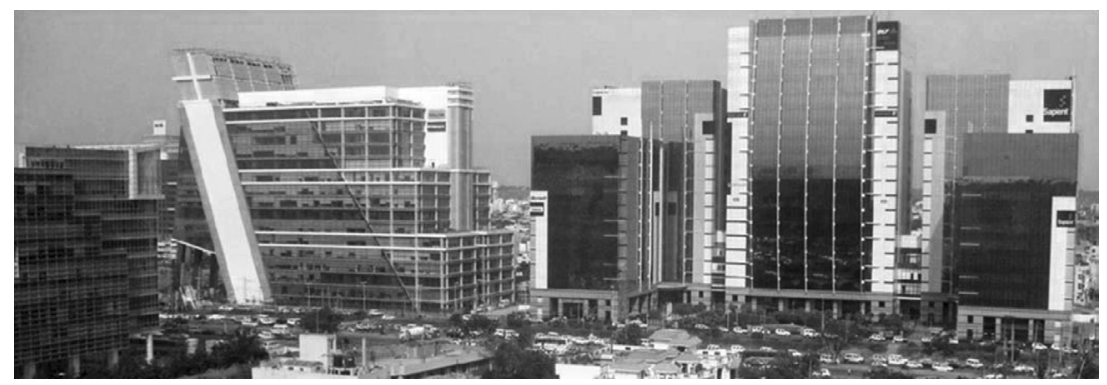

Source: gurgaon.nic.in

\section{Figure 10.2 Gurgaon}

while Gurgaon was largely barren, with no local government, public utilities, or transportation. As the New York Times (Yardley, 2011) noted, the development of the two regions since the split has been unexpected. Faridabad has struggled while Gurgaon has thrived, riding a wave of postliberalization growth and becoming an information technology (IT) hub and one of the fastest growing urban centres in India.

As late as 1991, the Gurgaon district had an urban population of some 121,000 ; by 2001, this had expanded to 870,000 and by 2011 to 1.5 million (1991 Census). ${ }^{3}$ As of 2013, nearly half of the Fortune 500 companies have operations in Gurgaon, including American Express, General Electric, Motorola, Dell, Microsoft, IBM, and Google. Many other leading firms from around the world have also chosen to locate in Gurgaon (Hindustan Times, 2013a). As a result, Gurgaon has become a leading destination for India's young middle-class workers in the tech industry. Along with these workers have come amenities. Gurgaon has 43 shopping malls, including the Mall of India - one of the largest malls in the world - many luxurious apartment towers, gleaming skyscrapers, seven golf courses, and at least half a dozen large five-star hotels.

Gurgaon has been called 'the Singapore of India,'4 but unlike Singapore, the public infrastructure in Gurgaon is poor. There is no citywide sewage, water, or electricity system. Sewage is often dumped in nearby rivers or open land. Groundwater is in short supply and is being rapidly depleted. Power outages are frequent. In addition, public transport is poor to nonexistent within Gurgaon (although a metro to Delhi opened in 2013). Security is also poor in public areas where police are undersupplied. In short, Gurgaon looks like Singapore in terms of private-sector development, but like other Indian cities in terms of public-sector development. 


\section{GURGAON: HISTORY AND DEVELOPMENT}

The key element in Gurgaon's explosive growth was the state of Haryana's lifting of restrictions on the land-acquisition process and the unusual lack of local government in Gurgaon. The lifting of restrictions and Gurgaon's natural advantage in being close to Delhi (itself labouring under restrictions) allowed private developers to build residences, office parks, and manufacturing facilities that met the demands of India's booming hightech sectors during the high-growth period that followed liberalization of key sectors in the early 1990s.

\section{Land Acquisition}

In much of the world, as cities have grown outwards and surrounding land has increased in value for urban uses, land has been converted as farmers have gradually sold to builders. In India the process is much more politicized, bureaucratic, and slow, because there are numerous restrictions on converting and buying agricultural land for non-agricultural use. We offer a sketch (for more details see: Palit and Bhattacharjee, 2008; Morris and Pandey, 2009).

As a general rule, each landowner must apply for permission for non-agricultural use under the specific zoning laws governing the city and state, and each application is considered on a case-by-case basis. A non-agricultural use clearance (NAC) is usually given only for a specific non-agricultural use, not as a general right that flows with the land. In other words, farmers cannot obtain the right to use their land for a non-agricultural use and then convey this right to any buyer. A farmer wishing to sell land for non-agricultural use must first find a buyer with a predetermined proposal for the use of the land and then apply for a NAC for that specific use. Instead of a market in land, there is a series of high transaction-cost bargaining games between sellers, buyers, and the state; each party being provided with plenty of opportunities for threats, holdups, and delays. As a result, individual buyers and sellers tend not to transact and only large firms with the ability to manage the government machinery end up obtaining NACs from the state government. Moreover, obtaining a NAC permission is only a first step. To actually build something or otherwise change the land use, developers must obtain a changeof-land-use permission (CLU). The entire process of land acquisition and development typically requires moving through many government bureaucracies.

Although it is extremely difficult for private developers to buy and convert agricultural land, there is a loophole. The colonial-era Land 
Acquisition Act of 1894 allows the federal and state governments to acquire land through the power of eminent domain for 'any public purpose or for a company' under Section 4(1). Similar provisions exist in the recently introduced Land Acquisition Act of 2013. Likewise, a private company is exempt from the restrictions of the Land Acquisition Act and permitted to acquire land if licensed by the state government.

In Haryana, the legislature passed several laws to enable large-scale land acquisition for private firms to develop townships. First, in the 1970s, the Haryana state government removed the tedious NAC requirement. Second, the Haryana Urban Development Authority Act of 1977 empowered the state to acquire agricultural land for developing townships. Concurrently, licences were given to private developers to develop the townships from large parcels of contiguous land under the Haryana Development and Regulation of Urban Areas Act of 1975. Easier land acquisition in Gurgaon helped private developers assemble parcels of land and also meant roads and highways could be more easily routed through Gurgaon while developing private townships. Since the land in Gurgaon was unproductive and sparsely populated, few objected to converting it into non-agricultural use (Debroy and Bhandari, 2009).

The Haryana Urban Development Act of 1977 established the Haryana Urban Development Authority (HUDA), a unified agency that would co-ordinate town and estate planning. Before the creation of HUDA, numerous departments and laws governed different aspects of the planning process with little co-ordination.

The Haryana administration has been praised for having a 'single window' clearance, a streamlined procedure, with relatively few requirements for permission for change of land use. On paper, the administration must still consider Change of Land Use applications, as per a multiplicity of zoning regulations, laws, and departments. ${ }^{5}$ However, both the Haryana Urban Development Authority Act (1977) and the Haryana Special Economic Zones Act (2005) allow the government to make exceptions.

\section{Local Government}

Faridabad, like Gurgaon, is in the state of Haryana and so also benefited from simplification of the land acquisition and development process. However, in addition to the state government's authorities, Faridabad also had a municipal government. Gurgaon, which was mainly agricultural wasteland, did not have a municipal government or any other 'urban local body' (ULB), responsible for urban planning and public goods, in the early years of its growth. 
Schedule 12 of the Constitution of India, created by the Seventy-Fourth Amendment (1992), granted statutory status to ULBs as the third tier in representative democracy and gave them authority over urban planning, including regulating land use, developing roads and bridges, managing the water supply and solid waste, and other local governmental activities. Based on the 1991 census conducted by the Government of India, Gurgaon did not meet the criteria of the Ministry of Urban Development ${ }^{6}$ for a ULB; nor did the state government of Haryana declare Gurgaon an urban area - that is, having a population of over 50,000 between the 1991 and 2001 censuses. Gurgaon slipped through the cracks and was not categorized as an urban area until 2001; this new categorization mandated that Gurgaon create a municipal body only in 2008 .

In the absence of a ULB in Gurgaon, the chief minister in Haryana had the key veto power in allowing land conversion and was also the main power centre granting licences to private land developers. Importantly, the chief minister of Haryana is also the chairman of HUDA. Thus decisions about land regulation have been the responsibility of a single office, the Haryana Chief Minister's Office (CMO). ${ }^{7}$

\section{Monopoly Corruption and Serial, Competitive Corruption}

Corruption in obtaining CLU permissions is common in most cities in India, and Gurgaon is no exception. Often, middlemen associated with the Haryana administration bought land from farmers and villagers by taking large loans from private developers, acquiring the requisite CLU permission, and then transferring the land to private developers. Corruption was especially acute in Gurgaon because land prices were increasing along with demand. Nevertheless, obtaining CLUs was still easier in Gurgaon than in other cities. Because Haryana's chief minister controlled the CLU permissions at the top, there were fewer legal or regulatory complexities. Thus, for developers, it was simply a question of settling on the appropriate price for the land and paying the requisite parties.

Comparing the development of Haryana with the rest of India illustrates the important distinction between 'monopoly corruption' and 'serial, competitive corruption.' A corrupt monopolist chooses the revenuemaximizing 'toll' - that is, a bribe - which entails not killing the goose that lays the golden eggs. In contrast, if the developer must pay a series of independent tolls, each being necessary to reach the final destination, the sum of the tolls can easily exceed the single monopolist's revenue-maximizing toll, thereby killing the goose. This is because the serial monopolists do not take into account the effect of their tolls on the profits of the other toll takers (Shleifer and Vishny, 1993; Gardner et al., 2002; Heller, 2008). 
Gurgaon was governed by a monopolist, the Chief Minister's Office of Haryana. Centralized control reduced transaction costs and also incentivized the CMO not to raise toll rates so high as to kill the goose. In contrast in Faridabad, decision-making and toll-taking was spread across many different bureaucracies and total tolls reduced development even below the rent-maximizing level, to the detriment of all.

\section{Private Developers}

The story of Gurgaon as a boomtown begins with land and infrastructure problems in nearby New Delhi, the Indian capital. Originally Delhi Lease and Finance (DLF) was one of the first developers in post-independence Delhi. Formed in 1946, DLF was active in developing neighbourhoods in Delhi until creation of the Delhi Development Authority in 1957 squeezed out private developers (Debroy and Bhandari, 2009). The Delhi Development Authority managed the supply and demand of land following the rigid control mechanisms of socialist planning. Zoning and land-use rules restricted the supply of land in Delhi, resulting in heightened scarcity, which in turn led to a proliferation of illegal construction and corruption in virtually all kinds of building and land allotment. With no revisions in the Delhi Master Plan until 2007, opportunities for legal real estate development shrank. Businesses and citizens looked to nearby Faridabad and Gurgaon for cheaper land and greater growth opportunities.

In 1979, with the split between Gurgaon and Faridabad, DLF began buying land in Gurgaon. Gurgaon's proximity to Delhi, as well as the Indira Gandhi International Airport (just 15 kilometres away) made it an attractive location. From 1981 to 1982, DLF and Ansal Properties, another big Delhi-based property developer, received licences from the Haryana state government to build large private-sector residential townships. This was the beginning of development in Gurgaon, led by the private sector.

In addition to developing residential areas, DLF assembled parcels of land for commercial use. Between the mid-1980s and 1990s, Gurgaon developed as Delhi's industrial and residential suburb, but this was a slow process. The industrial era of Gurgaon began with the establishment of an Indo-Japanese joint venture in 1982, the Maruti-Suzuki automobile plant and its ancillary factories. In another important collaboration, Hero Motors and Honda set up a plant in Gurgaon in the mid-1980s to manufacture motorcycles. Several other factories in such diverse industries as car components, telecommunications equipment, and fashion garments followed this trend and started establishing operations in Gurgaon.

Subsequently, growth turned Gurgaon into one of the major information 
technology/business process outsourcing (IT/BPO) hubs in India, and the city grew rapidly. An important turning point was when Jack Welch, then chairman of General Electric (GE), met with the telecommunications minister and the prime minister of India in 1989. General Electric started partnering with Indian firms and started the outsourcing revolution in India (Solomon and Kranhold, 2005). After the 1991 reforms liberalizing various sectors of the Indian economy, domestic manufacturers faced stiff competition from foreign companies. However, it was the service industries, and IT and IT-enabled services (such as business process outsourcing) in particular that became the most important export industries. The rapid rise of the export-oriented IT/BPO industries required large floor spaces that large private entities were willing to supply in Gurgaon (Debroy and Bhandari, 2009). American Express, for example, followed the example of GE in setting up one of its largest global credit-card operations in Gurgaon. As IT workers moved to Gurgaon it became even more cost-effective for firms to establish operations in Gurgaon. The city grew rapidly, following an agglomeration process familiar from the history of other industrial cities such as Detroit, Michigan; Bollywood in Mumbai, and Silicon Valley in California (Glaeser, 2008).

Typically, these multinational corporations leased parcels that had been developed as business parks by private developers such as DLF. These parks were developed to the specifications of big firms, keeping in mind the type of operations to be carried out and the requisite infrastructure. All these business parks came with full electricity backup (to ensure seamless operation during electricity outages), security personnel and infrastructure, parking lots, cafeterias, and so on. Leasing space tailored to the needs of IT and other outsourcing operations provided operational flexibility to these corporations. This also meant that multinational firms did not have to struggle with land-acquisition problems to set up their operations in India (Chatterjee, 2013).

\section{Urban Government in Contemporary Gurgaon}

In 2008, the Municipal Corporation of Gurgaon (MCG) was created but its authority is limited. ${ }^{8}$ Only old Gurgaon (about 35 square kilometres), which was previously under the municipal committee, and 37 village pockets, which were previously under the panchayats ${ }^{9}$, are now under the direct control of the MCG.

On paper, once HUDA or private developers build roads, public infrastructure, drainage systems, and so on, they need to hand these developments over to the MCG for maintenance. However, there is neither any timeframe nor any agreement between the two bodies on how to account 
for the civil works undertaken so far and the extent of the tasks still pending. It is still unclear where the responsibility lies for maintenance of public utilities and infrastructure in Gurgaon. In the development and maintenance of HUDA areas, there is no clear link between the authority and the citizens in the area. If citizens wish to complain about the lack of sanitation, garbage disposal, and other infrastructure in a HUDA area, they have no redress mechanism, while the MCG has a clear redress mechanism, but no authority (Singh, 2012).

Thus, given the haphazard nature of Gurgaon's development, as well as conflicts between various power brokers engaged in the governance of the city, the jurisdiction of the MCG is still unclear and it wields little authority in the areas demarcated by the Seventy-Fourth Amendment. The three areas of Gurgaon, controlled by HUDA, the MCG, and private developers, respectively, have no coordination.

\section{PROVISION OF PUBLIC GOODS AND PRIVATE SECTOR RESPONSES}

In Gurgaon, the private sector has stepped in to address many of the failings of the public sector, with mixed success. Private suppliers have responded to the failure of the public sector by creating private sewage, water, electricity, and security. On the surface, these private systems work well for those paying, but looking beneath the surface, the costs are high. Private sewage systems, for example, often do not connect to official sewage lines, but instead lead to tanks that are periodically dumped, sometimes illegally. Private wells are common and water is tanked in, but groundwater is being dissipated and tanked water is expensive. Private electricity is far more reliable than the public system but suffers from smaller-than-efficient scales of production and excessive pollution. Private security does a good job protecting the middle class, but public spaces are unprotected, a contrast that harms even the protected, who appear to have developed a siege mentality. We discuss the public and the private provisioning of these services in detail.

\section{Sewage}

Water and sewage provisioning is among the biggest problems faced by Gurgaon. Prior to Gurgaon being designated an urban area in 2008, it followed no master plan for water, sewage, and drainage lines. The biggest damage done by this organizational confusion is the lack of a unified water and sewage system for the city. As a result, residents cannot take 
sewage treatment for granted, as there is often no connection to a public sewer line. Even when such a connection exists, sewage treatment at the public plants is often ineffective. Public health and sanitation is especially poor for slum dwellers in Gurgaon, who lack toilets and suffer from illegal dumping of sewage created elsewhere. Illegal dumping of sewage in common areas and water bodies has also begun to contaminate the groundwater. The Centre for Science and Environment (CSE) estimates that by 2021 Gurgaon will be generating 533 million litres per day of sewage but will have the capacity to treat only 255 million litres per day (CSE, 2012, pp. 117-25). Sunita Narain of the CSE predicts that Gurgaon will be a city 'drowning in its excreta.'

Two public agencies supply water and sewage in Gurgaon, depending on the administrative divisions: the Haryana state government's Public Health and Engineering Department (PHED) is responsible for the old city area (municipal limits), while the Haryana Urban Development Authority takes care of the new city. The PHED claims that about 80 per cent of the population in the old city is connected to the official sewage system. The HUDA Engineering Department has divided the city into four zones. According to the agency, the total length of the sewers in zones I, II, and III is about seventy-four kilometres, 92 per cent of which is laid and functional. Zone IV has 40 kilometres of sewers, of which 32 kilometres have been laid; the remaining sewage construction has been held up due to litigation. Some of the new colonies remain either unconnected or partially connected to the main line; for example, only 40 per cent of the total DLF area is connected at present. Overall, about one-third of Gurgaon is connected to an official sewer line.

Two public sewage treatment plants, in Dhanwapur and Berhampur, serve the one-third of Gurgaon lucky enough to be connected to a main sewage line. Neither of these plants functions well. In March 2012, the Haryana State Pollution Control Board sent a notice to HUDA for poor maintenance. In their test of random samples of treated wastewater, they found aqueous pollutants at 182 milligrams per litre, while the average for municipal sewage after a three-stage treatment process is 20 milligrams per litre or less. In Gurgaon, even treated wastewater remains waste.

Private developers of residences and commercial parks have responded to the lack of public sewage by providing some waste-treatment services. Most apartment complexes include a sewage treatment plant. Once the waste is treated, tanker trucks transport the waste to the Yamuna River. Usually, apartment residents are charged a fee for this service. Similarly, industrial parks like Genpact have their own sewage treatment plants. Within the industrial park, they lay the sewage lines and treat the waste. 
One part of the treated wastewater is reused and the rest of the treated waste is transported to the treatment facility or the river. However, not all private developments have a sewage treatment plant. Many developments have sewage lines within the development, but these lines do not connect to the main lines or a sewage treatment plant. In these private developments, the management fills sewage in septic tanks, and either takes the tanks to the public treatment facilities, which as noted earlier do not work well, or illegally dumps them in common areas (TNN, 2010).

A maintenance engineer at UNITECH Group (who has chosen to remain anonymous) explains:

We contract with tanker companies that provide us with septic tankers for our buildings. There is a clear understanding between officials and tanker operators. Tankers routinely dump untreated waste outside Gurgaon in informally allotted wastelands. The officials look the other way. Anyway, the treatment plant is overflowing and there is nowhere else to take the waste. There is no alternative.

In one sense, when private developers transport sewage and wastewater out of homes and neighbourhoods for a fee, this results in a better and more sanitized solution for residents compared to the slums and old Gurgaon villages where residents, in the absence of any sewage lines, are wallowing in their waste. However, private provisioning does not solve the problem of waste management. Developers merely dump treated and untreated waste in an unseen common area or river, far from the private development. Whether the waste is dumped illegally in open areas, or in the treatment facility flowing to the river, the waste management system contaminates common resources like groundwater and river water and is at present dysfunctional.

\section{Water}

The responsibility for water delivery in Gurgaon varies by administrative division: the PHED is responsible for the old city (municipal limits), while HUDA takes care of the new city. The Haryana Urban Development Authority is responsible for sourcing and treating water for its sectors and for transferring water to PHED for supplies within the old city limits.

Overall, only two-thirds of Gurgaon residents have access to piped water, and supply is intermittent. Given the shortage of this water supply, 70 per cent of all residents (including those connected to piped-water supply lines ${ }^{10}$ ) depend on groundwater that is privately provided (Yadav, 2012).

Private water providers cover the shortage of water for a fee. Gurgaon residents buy water for both potable and other uses. Private water tankers 
visit residences and neighbourhoods and fill the water tank of each home. In the case of apartments, builders sometimes also have a tubewell on the site, and legally or illegally tap groundwater and treat it for use by the residents.

Thus while residents are willing to pay for private water provision, private water providers are depleting groundwater in Gurgaon. Vinay Shanker of Mission Gurgaon Development estimates that half the 30,000 bore wells in Gurgaon are illegal (CSE, 2012). According to Dr Gauhar Mahmood of Jamia Milia Islamia University, every year Gurgaon consumes around 30,000 hectares of groundwater above the yearly cap of 20,000 hectares (see also TNN, 2013a). Gurgaon is extracting groundwater at a much higher rate than it is replenished by rainwater.

Aside from residential use, a second reason for the illegal and indiscriminate use of groundwater is the booming construction industry in Gurgaon. Last year, the Punjab and Haryana High Court directed HUDA to cease granting fresh construction licences in order to reduce the amount of water required for construction purposes (Kumar, 2012).

While acknowledging the acute water shortage, HUDA has announced that the solution is to create a separate water administration authority in Gurgaon and to increase water supply through rainwater harvesting and treatment of sewage and wastewater (Dhar, 2013). On 1 October, 2013, the MCG took over the water supply of Gurgaon from the PHED. The MCG will now be responsible for the water supply in the entire MCG area, excluding the HUDA sectors, private-builder areas, and HSIDC areas. The entrance of the MCG has not yet given Gurgaon a unified water-sewage system (TNN, 2013a). A member of the new MCG commission (who wishes to remain anonymous) said that: 'HUDA is only creating new water boards and MCG to have more bodies to blame. Water is too important an issue in India for the chief minister to relinquish control. This will only create more bureaucracy and people will continue to get private tankers.'

\section{Electricity}

Most urban areas in India have significant shortages of electricity and Gurgaon is among the most affected. Power is produced mainly in two state-owned plants: a coal-fuelled thermal power plant with 600-megawatt capacity in Yamunanagar and another in Hisar with two units, each with a generating capacity of 600 megawatts. Haryana's state-run distribution company, Dakshin Haryana Bijli Vitran Nigam (DHBVN), distributes approximately 16 million kilowatt-hours of electricity each day in Gurgaon. Gurgaon consumes 33.9 per cent of the load of DHBVN and 
contributes 40.4 per cent of its revenues. Officials at DHBVN say the supply of electricity is about 25 per cent short of demand (Raina, 2012). Residents and businesses in Gurgaon estimate the shortfall at a higher number because they face 10- to 12-hour power outages, especially in the summer when temperatures can soar to over $45^{\circ} \mathrm{C}$.

Private providers alleviate the acute shortage caused by state provisioning for every type of industrial, commercial, and residential use. Industries consume 45 per cent of the electricity (Singh, 2013); they face outages, and in some cases receive power only during non-peak hours in the afternoon and at night. Small- and medium-sized enterprises are most impacted by power outages and the high cost of electricity. Some of them are leaving Gurgaon for this reason (Alam, 2013). Large manufacturing plants supply their own power with large and, relatively speaking, efficient diesel generation.

Commercial parks account for 32 per cent of the electricity consumption. These firms, mostly performing IT/BPO functions, cannot afford to have any downtime caused by power outages and have seamless and continuous power backup using large diesel generators. For instance, Genpact, which has 11,000 employees and works three shifts through the day and night, has 12 diesel generators for continuous electricity. It uses about 5,000 litres of diesel a day in the summer. This increases the cost of operations by 50 per cent (Raina, 2012).

Private residential developments typically offer their own backup power supplies using diesel generators or have generators or invertors for each home to deal with 10- to 12-hour outages in the summer. Private developments charge a premium for the provision of this service and different residential parks advertise that they have 100 per cent backup, or 80 per cent backup, although in the case of individual homes, they may provide no power backup at all.

Private electricity generation meets a demand. Overall, the private electricity generation capacity in Gurgaon is on the order of 2,000 megawatts, exceeding the public capacity (Bureau, 2013). In total, public and private capacity is more than Gurgaon needs, but power is inefficiently supplied. Just as a failure of public transport can lead consumers to overinvest in private automobiles, which remain idle for most of the day, the failure of public electricity generation has led consumers to overinvest in generators, which remain idle most of the time. Currently, there is also no way for private generators to sell their capacity back to the grid which - by assigning production to the least-cost suppliers first - would reduce the incentive to overinvest and improve efficiency.

Total costs in Gurgaon are high because each provider is producing electricity using expensive diesel-based engines, which also pollute much 
more than big electric plants. Clear norms govern the type of diesel, the amount of electricity generation that is permitted, and so on, for approved and licensed use of diesel-based generators in industrial plants. However, small residential associations or individuals generate most of the electricity extra-legally, with diesel generators in their backyards, and there are no norms in place for the regulation or monitoring of such generators. As a result, air in Gurgaon has high levels of carbon monoxide, sulphur dioxide, and nitrous oxide.

According to a recent Hindustan Times-Fore survey, 61 per cent of Gurgaon residents felt that power distribution in Gurgaon should be completely private, as in Delhi; 81 per cent expressed willingness to pay a premium to private companies for uninterrupted power (Jha, 2013).

\section{Crime}

Overall crime rates in Gurgaon are modestly higher than in Delhi and Faridabad - especially for theft. In 2012, there were 82 murders in Gurgaon and 72 in Faridabad (National Crime Records Bureau, 2012). By comparison, the numbers are about the same as in Phoenix, Arizona, but significantly lower than in Philadelphia, Pennsylvania, two American cities of comparable size. Security is typically worse in public areas than in private ones.

Private security firms abound in Gurgaon. A quick search at JustDial. com, an Indian search engine, finds dozens of security firms, such as G4S, also a leading private security provider in the United States. It is common for private homes to have personal security guards, and housing complexes, apartments, shopping malls, street stores, and places of work all have private security. Overall, there are some 35,000 private security guards working in Gurgaon compared with just 3,100 public police (Yadav, 2011).

Firms make arrangements for the security and transportation of their employees. Genpact has 350 private drivers, whom they pre-screen before hiring. These drivers travel roughly a hundred thousand kilometres every day, transporting ten thousand employees to and from the office. Employees book daily online reservations and receive 'tickets' for their assigned cars. In the parking lot, a large screen posts lists of cars and their assigned passengers, as in airports. Genpact has installed GPS devices inside every employee's private car and hires security guards at night to escort female employees to their homes (Yardley, 2011).

Some BPO operations have set up 24-7 emergency control rooms with helpline numbers for female staff. These initiatives are an attempt to create a 'first ring of safety' for women, parallel to the police system. It 
constitutes an internal and dedicated mechanism to ensure safety (Ahuja, 2013a).

On an objective basis, private security works well in Gurgaon. Security is very good for the middle class, but admittedly less so for the poor, as is true in the rest of India. Subjectively, however, many members of the middle class do not feel secure and instead see themselves as living on islands of private security surrounded by a sea of criminality. ${ }^{11}$

Private security protects people as they travel through Gurgaon, much like private security was used to protect US officials moving through Baghdad. Unlike Baghdad, Gurgaon is peaceful and relatively safe for a city of its size. Nevertheless, the structure of security leads to perceptions of insecurity: perceptions that private security providers have no incentive to alter. A different structure of protection could mitigate such feelings of insecurity. Instead of protecting individuals and particular places, private policing could be used to protect larger neighbourhoods or regions. San Francisco, California, for example, has had a private police force protecting some downtown areas for over 168 years, and private policing has recently become more common in some neighbourhoods in Oakland, California (Stringham, 2009; Kane, 2013). Thousands of homeowner associations in the United States contract with private security firms. Neighbourhood purchase of security, however, requires some collective organization or a more encompassing unitary organization. We return to this theme at greater length later.

\section{Fire Stations}

Fire management is yet another area where the private sector has stepped in. When the MCG took over in 2008, Gurgaon had only 14 public fire engines and 23 fire officials to tackle potential emergencies in a city with 400 high-rise buildings (15 metres or higher) and about 7,000 industrial units, spread over 1,500 square kilometres. The federal Indian government's norms require that urban areas have one fire engine and five firemen for every 50,000 persons. By this requirement, the MCG would need at least 42 fire engines and 210 firemen. Government norms also require a three-minute response time in case of a fire (Chowdhury, 2009). It is no surprise that the response time for publicly provided firemen in Gurgaon is much longer, at 25 minutes. In 2010, the MCG decided to purchase fire bikes to cut through traffic congestion in Gurgaon and reduce response time.

Aside from lacking enough infrastructure, Gurgaon has also struggled with providing the right type of infrastructure. Rescuing people and extinguishing fires in a high-rise requires high-rise equipment. Gurgaon had 
two hydraulic pumps that enabled water to reach a maximum height of 40 metres, less than half the height of the tallest high-rise. The MCG also passed a proposal to procure 101-metre-high turntable ladders to combat fires in high-rises (Ahuja, 2010). This has still not been put into effect. The fire department has additionally requested of HUDA that fire stations be set up every five kilometres in Gurgaon, but there has been no action on this policy yet, either. Most big commercial and residential parks, however, have a fire protocol in place, some required by multinational corporations using the space, and others demanded by citizens and residents.

In Gurgaon, in addition to the three state-run fire stations' equipment, private companies own another six fire tenders. As well as fire-fighting equipment in its various buildings, DLF has fire protocols. In 2012, DLF set up India's first private fire stations in Gurgaon's districts Cyber City and DLF Phase V, with equipment specifically fitted to deal with high-rise buildings. The DLF fire station has two 90-metre-high hydraulic platforms, capable of reaching Gurgaon's tallest buildings. Also, DLF provides two fire tenders per station, with the fire dousers having the capacity to carry 18 kilolitres of water per vehicle. The head of fire safety at DLF has 120 firemen reporting to him, primarily to respond within DLF areas. All costs of maintaining the equipment, systems, and personnel are borne by DLF (DLF Press Release, 2012).

Not only does DLF provide for a fire brigade privately, the equipment in DLF fire stations is better than the equipment elsewhere, including the city of Mumbai, which only operates up to a height of 70 metres. A member of the DLF fire management team (who wishes to remain anonymous) explained the advent of the private fire station as follows:

The government equipment is a joke. They are using a pichkari ${ }^{12}$ to fight fires in high-rise buildings. DLF cannot do that. We have thousands of crores' 13 worth of investment that we must protect. Now we have built a world-class fire brigade.

When asked about fires in non-DLF properties, he explained that 'a fire accident in Gurgaon is not good for anyone. DLF is now synonymous with Gurgaon, and a fire in Gurgaon will tarnish our name.'

\section{Roads and Transport}

Transport infrastructure as well as transport delivery in Gurgaon is abysmal. Gurgaon has no unified agency for building and maintaining roads. ${ }^{14}$ Gurgaon has a poorly maintained road network; it had, until recently, no provision for public transport, whether mass transit or bus 
service, which made road congestion worse; and not all of Gurgaon's parts connect to the Delhi Metro's mass transit system. In private developments, each household has at least one car (often one car per member of the household) and the city adds 60,000 cars to its roads every month. Poor commuters rely on auto-rickshaws, cycle rickshaws, and overflowing private buses. Congestion is an enormous problem.

As late as circa 2005-2009, Gurgaon had only 1.6 kilometres of surfaced road per thousand persons. ${ }^{15}$ In contrast, San Francisco has on the order of ten kilometres of higher-quality roads per thousand persons. The numbers had not much improved by 2013. The problem is not just too few roads, but also poor-quality roads and poorly planned junctions and tollbooths. In public areas, the roads usually do not have working traffic lights or traffic police. Even the best public roads have problems. For instance, the Delhi-Gurgaon Expressway, a 28-kilometre toll expressway, is one of the most modern roads in India. The road's quality is good but a poorly run toll collection system means regular traffic jams with queues of over one kilometre and up to an hour in waiting time twice a day, leading one news source to ask, 'Is the Delhi-Gurgaon Toll Road the Worst in the World?'16 Courts recently ordered the suspension of toll collection until the authorities can figure out a way to remove congestion at the tollbooths (Ahuja, 2013b).

Within private developments in Gurgaon, the roads are of good quality. For example, DLF and HUDA are building a 16-lane, 8.3-kilometre road network within Gurgaon to connect the National Highway, the DelhiGurgaon Expressway, and the main sector roads of Gurgaon to the Delhi Metro and the new Rapid Metro lines. This network mostly connects DLF developments, both industrial and residential. ${ }^{17}$

Gurgaon also has a bus depot and a bus fleet (Haryana Roadways), but both are quite dysfunctional. The bus fleet does not cover important routes and is not frequent or reliable enough for citizens to use as a primary mode of transport. While around 150 people maintain a fleet of more than 250 buses, no new appointments have been made at the bus depot since 1993 and there is a shortage of bus drivers. As of mid-2013, Haryana Roadways operates only 110 buses on 15 routes in two shifts (Hindustan Times, 2013b).

Once again, the shortfall is covered by the private sector: bus, autorickshaw, and taxi operators, many of whom are unlicensed. These private modes of transport are often filled with twice the suggested capacity of the vehicle, because there is a high demand for transport, especially in poorer neighbourhoods. Most companies provide or contract out their own bus service for employees and also have a car fleet available for employees who work unconventional hours to meet foreign customers' schedules. In 
2013, the Haryana government announced a new policy to help develop a private bus fleet in Gurgaon, including approving 21 new inter-district bus routes and granting 90 licences to private operators (TNN, 2013b).

Given the high population and density in commercial parks, Gurgaon is an ideal place for rapid mass transport. The Delhi Metro connects Delhi to Gurgaon; however, the Gurgaon government did not develop a transit system to connect all of Gurgaon to these stations. The new Rapid Metro in Gurgaon was built by DLF and Infrastructure Leasing \& Financial Services Limited (IL\&FS), a large infrastructure development firm, with HUDA providing the requisite land. This 5.5-kilometre line connects Delhi Metro's Sikanderpur station to DLF Phase III, a key DLF-developed property, with stations in progress at other DLF residential and commercial developments as well (Joseph, 2013). This is India's first fully privately financed metro system. It was built at a cost of nearly 1,100 crore rupees and it took 30 months to complete construction of Stage 1, which started operations in mid-November 2013. After the early development stages, DLF sold its share to IL\&FS and the project has been launched in the public-private partnership mode (India Today, 2013). Over 100,000 commuters are expected to travel by metro daily in the first year, and carbon emissions in Gurgaon are expected to fall by 90,000 tons (Dabas, 2013).

\section{THE FAILURE OF GURGAON'S DEVELOPMENT IN THE INDIAN CONTEXT}

Gurgaon's failures are often noted but rarely have they been put into context. Gurgaon has suffered from the lack of a cohesive urban plan, but urban growth has vastly outpaced planning efforts in almost all Indian cities. Indian cities as a group have failed to provide appropriate and safe infrastructure to meet the demands of the Indian population. ${ }^{18}$ Though public sewage provision in Gurgaon is appalling and in marked contrast to its gleaming private residences and workplaces, it is actually of above average quality by Indian standards. Consider that 4,861 out of the 5,161 cities and towns in India do not have even a partial sewage network. In Bangalore and Hyderabad, two of India's other large 'hightech' cities, almost 50 per cent of households do not have sewage connections (Ahluwalia, 2011). On a National Urban Sanitation Policy ranking of overall sanitation quality in 2009-2010, Gurgaon ranked 88th out of 423 large Indian cities (Ministry of Urban Development, 2009-2010). Gurgaon had the second-best ranking in the state of Haryana. Most telling, Gurgaon ranks well above its sister city of Faridabad (ranked 
240th), a city of comparable size in the same state situated only 41 kilometres from Gurgaon.

Water supply is also poor in most of India. Half of India's cities have no piped water supply system and in those cities with a piped supply, the daily duration ranges from one hour to six hours (Ahluwalia, 2011; Nelson, 2011). Most of India's cities face severe water shortage problems and groundwater dissipation. Harris (2013) argues that the country's struggle to provide water security even just to the 2.6 million residents in the state of Meghalaya, blessed with more rain than almost any other place on the planet, shows that the problems are not all environmental.

Power failures are common in Gurgaon; they are also common throughout most of India. In July 2012 India faced the world's largest power failure when 680 million people (about 10 per cent of the world's population) were thrown into the dark (Sharma et al., 2012). For those with access to electricity, outages are a fact of everyday life. Moreover, more than 300 million people in India still have no access to electricity at all.

The situation is much the same for public transportation. According to the Ministry of Urban Development's Report on Indian Urban Infrastructure and Services, 'only 20 out of India's 85 cities with a population of 0.5 million or more in 2009 had a city bus service' (Ahluwalia, 2011). The report goes on to note that the problem is not only linked to poverty, as India's rate of public transport is less than half that of other developing economies. Instead the result is due to inadequate investment, a tax structure that is biased against public transport, and infamous red tape from multiple and overlapping regulatory authorities. Only a handful of Indian cities have a mass transit system.

Fully 25 per cent of Indian villages still have poor road links. ${ }^{19}$ Of India's two million kilometres of roads, only.96 million are surfaced and about one million are poorly constructed. India's 53 national highways carry about 40 per cent of the total road traffic. In all urban areas congestion is a massive problem.

\section{ANALYSIS: A FAILURE TO INTERNALIZE EXTERNALITIES}

The successes and failures of private development in Gurgaon provide strong support for the standard economic model: markets and profitseeking firms are challenged by externalities and public goods. Our choice of the term 'challenge' is deliberate. Externalities and public goods do not necessarily lead to market failure (Beito et al., 2002). Private firms have addressed most challenges and they have provided sewage, water, 
electricity, roads, transportation, security, fire prevention, and other goods. But to address is not necessarily to overcome, and some challenges have been met only at high cost. Crime prevention has been good and fire prevention arguably better than that publicly provided, but few would argue that Gurgaon's sewage, water, transport, and electricity systems are ideal, even if they are sometimes better than the Indian average.

The government has failed to provide Gurgaon with large-scale infrastructure. In theory, water, sewage, roads, and electricity could be provided at scale by private, natural monopolies - albeit at potentially high prices. But instead of natural monopolies, Gurgaon has developed a competitive system of private suppliers. Competition among private suppliers has produced two failures. First, prices of water, electricity, sewage, and so forth are close to marginal cost but average cost is far too high because of the failure to exploit economies of scale. Second, competitive suppliers have produced negative externalities such as excess pollution, sewage dumping, and groundwater dissipation. Why hasn't the private sector done better? We address the two failures in turn.

\section{Natural Monopolies}

Why hasn't Gurgaon developed natural monopolies, at least for urban infrastructure such as water, electricity, and sewage? It is far more expensive to build urban infrastructure after development than before development. After development has occurred, negotiating rights of way, digging up roads to create water and sewage pipelines, stringing or burying electric cables, and so forth necessarily requires the involvement of multiple parties. Negotiation costs increase with more players; holdouts are in a much stronger position if their permission is required than if land is bought with pre-planned encumbrances set aside for future infrastructure.

Political transaction costs may also increase with development. After development has begun, multiple layers of local and central governments and regulatory authorities will also have greater power to extract rents, and some may not even want infrastructure development. In one interview, a former member of the MCG (who chose to remain anonymous) explained how political considerations have increased transaction costs and discouraged collaboration:

Different private developers have different political patronage. DLF is close to Congress and CMO and gets the biggest tenders and benefits. Other developers have allied with local MLAs or with Lok Dal (now in opposition). None of the developers can manage to function without their political patrons, and therefore are on opposing sides. 
A citizen leader of one of the resident welfare associations in Sushant Lok (developed by ANSALS group) told us that corruption means that members of the government can actually profit from shortages because 'the government diverts power to its constituents.' The story is reminiscent of the political economy of the Soviet Union where shortages were pervasive because shortages generated rents for the political elite (Smith, 1976; Shleifer and Vishny, 1992). Some private firms may also benefit from a failure of co-operation, as our interviewee also expressed.

Compare Gurgaon's development with that of New York. In 1807, at a time when only the southern tip of Manhattan was urbanized and the population of New York City was just 85,000, the Common Council of the City of New York created a commission that laid out roads and public squares for the entire island (Angel, 2012). The commissioners planned for a sevenfold expansion, an expansion that would not occur for many decades (the population of the planned area would eventually number over two million). When Manhattan did expand, however, public rights of way for streets, sewers, parks, and other urban infrastructure had already been provided for, greatly reducing the cost of expansion. In essence, the Common Council planned the future rules of the game behind a 'veil of uncertainty' that gave them stronger incentives to plan for efficiency and the common good. Once the veil is lifted, however, the constitutional moment is lost (Buchanan and Tullock, [1962] 1999).

Transaction costs appear to be the key barrier because the largest developers, such as DLF, have provided infrastructure in keeping with the scale of their operations. Private developers have built sewage lines and even small treatment plants within a development but they have not cooperated with other developers to build a more extensive sewage system. The same has been true for water and electricity. In other developments, small and big, private firms have built parks, green belts, and landscaping, and provided crime and fire prevention. Private developers, however, have mostly been unable to provide goods beyond their own property line by cooperating with other developers or with the state.

Gurgaon is a new city and we may see more co-operation in the future as breakneck growth slows and attention turns to working out the kinks in the system. More recently, for example, DLF and IL\&FS have cooperated to produce the Gurgaon Rapid Metro system, India's first privately financed metro. In its first phase, it largely connects DLF offices and residences, but it will have benefits throughout Gurgaon. The metro is now being operated and maintained by another private consortium led by Siemens Ltd. Similarly, DLF is building a new highway project that initially connects DLF phases but may also be extended. Nevertheless, more 
extensive initial planning would have greatly lowered the transaction costs of post-growth infrastructure development.

\section{The Tragedy of the Commons}

While private firms have under-produced services such as sewage disposal and piped water, they have overused common resources by dumping waste, diminishing groundwater at unsustainable levels, and polluting the air with diesel fumes.

The primary problem has been a failure of the state to prevent exploitation of collective property. Gurgaon has too many state agencies and too little state enforcement. Government agencies like HUDA and the MCG often violate the norms set by the government and are unable to enforce the rules against dumping in the commons. A stronger but limited state is one solution (Hardin, 1978), but there are others.

One way to ensure that private developers do not dump waste in common land is to privatize the common land (Coase, 1959, 1960; Demsetz, 1967). Coase (1959, p.14) argues that:

[a] private-enterprise system cannot function properly unless property rights are created in resources, and, when this is done, someone wishing to use a resource has to pay the owner to obtain it. Chaos disappears; and so does the government except that a legal system to define property rights and to arbitrate disputes is, of course, necessary.

In Gurgaon, private developers manage their properties well. One does not hear of instances where DLF dumps its sewage wastewater on land belonging to ANSALS. The instances of dumping are on common properties, with the state as a complicit partner. Given the soaring land prices in Gurgaon, privatizing land and bodies of water would ensure that developers would protect their investments and force dumpers to internalize their externalities. No commons, no tragedy.

A third solution is the evolution of local institutions that deal with free-rider problems and externalities from the ground up (Ostrom, 1990). In Gurgaon, there has been a slow emergence of citizens groups, environmental groups, and resident welfare associations to monitor the commons. Citizen groups, for example, have used judicial activism as a tool to prevent overextraction of groundwater for construction purposes. The expansion of civil society in Gurgaon, however, is slow. A rapidly changing urban region with newly arriving people with little history of interaction is far from the ideal landscape for the evolution of a well-governed commons (Ostrom, 1990). 


\section{NEW CITIES OF THE FUTURE: LESSONS FROM WALT DISNEY WORLD AND JAMSHEDPUR}

Gurgaon would have done better with greater government planning and foresight, but if wishes were horses, beggars would ride. Is there an alternative path that could have performed better and yet was still plausibly within the feasible set? Pramod Bhasin, non-executive vice chairman of Genpact, expressed his frustration at how Gurgaon had developed without appropriate infrastructure, noting that 'our focus now is, how do we cope with this. [. . .] We provide our own security, our own transport, power, education and training. At some point I feel like telling them to give the city to us and we'll run it' (Kumar and Misra, 2012). Is it viable to turn a city over to the private sector?

Recall that developers have developed infrastructure within their own property line. If the property line were to be extended so would the infrastructure. In particular, if the government had allowed, or even required, much larger initial purchases of land then entire competitive cities could have been built under the umbrella of a single firm. A single firm seeking to maximize the rents from a large urbanizing area would have an incentive to build infrastructure - such as sewage, water, and electricity - that would cover the entire area under its purview.

\section{Walt Disney World: The City as a Hotel}

Are there examples of such systems in practice? Yes. Consider the Reedy Creek Improvement District in Florida, better known as the home of Walt Disney World. In the 1960s, Walt Disney bought up 25,000 acres (approximately 100 square kilometres, a bit smaller than San Francisco) of remote, undeveloped, and uninhabited Florida real estate. The property had no infrastructure, the nearest water and power lines were miles away, and the local government had no resources to build infrastructure. In 1967 the Florida state legislature and the Walt Disney World Company created an innovative form of governance. The legislature created a special taxing district, the Reedy Creek Improvement District (RCID), which in essence ceded governance to the Walt Disney World Company (WDWC). ${ }^{20}$

The RCID has control over planning, zoning, building codes, water, waste disposal, airports, roads, fire fighting and prevention, utility services, and security. It has built and maintains 215 kilometres of roadway, which brings 250,000 guests to Walt Disney World daily. The district has also built and maintains 107 kilometres of waterways. Fire prevention and emergency medical services for the millions of yearly guests are handled by the RDIC. The district includes its own electricity generation 
and distribution system, a water treatment facility and recycling centre, a potable water production and distribution system, a natural gas distribution system, public transport systems - buses, ferries, and monorail - that carry millions of passengers a year (both within Disney and between the airport and Disney), a wildlife conservancy area, 40,000 hotel rooms, hundreds of shops and restaurants, and the rides and attractions that have made Disney famous. Disney collects 60,000 tons of waste and 30 tons of aluminium, paper, steel cans, cardboard, and plastic containers for recycling every year. The garbage disposal system is innovative, using underground vacuum tubes to whisk garbage to a central processing station.

Disney produces infrastructure and public goods because infrastructure and public goods increase the value of Walt Disney World. More generally, the benefits of local public goods are capitalized into land rents (see Mieszkowski and Zodrow, 1989; Scotchmer, 2002). Indeed, at optimal levels of population, taxes from land rents will cover the entire value of public good provision, the so-called Henry George Theorem (Arnott and Stiglitz, 1979; Foldvary, 1998). Intuitively, visitors will pay more to visit places that are fun, well-functioning, clean, secure and attractive. Visitors, however, are no different in this respect than residents. Walt Disney World is like a city, a hotel city, whose residents simply stay for shorter periods of time than the residents of other cities. Hotels also produce public goods such as common areas, sewage, centralized heating and lighting, security, and so forth. The city as hotel is a way of bringing the benefits of competition and innovation that we see in hotels to the larger urban area of cities (MacCallum, 1970, 2002; Foldvary, 1994).

Walt Disney World is one of the largest private governments but in the United States there are also hundreds of thousands of typically smaller private governments in the form of homeowner associations, planned communities, condominiums, and co-operatives. In 2012 these private associations governed some 25.9 million housing units and 63.4 million residents (Foundation for Community Association Research, 2012). These governments provide all manner of services from safety and security to snow removal, garbage collection, public transport, and in some cases even medical centres and other infrastructure and services (Nelson, 2005; Agan and Tabarrok, 2005; Beito et al., 2002).

\section{Jamshedpur: A Privately Run City}

It is not just outside India that one finds private cities as examples of good governance. Jamshedpur is a private township and one of the best-governed cities in India. Jamshedpur was the idea of visionary businessman Jamshetji Nusserwanji Tata, who, after travelling to the United 
States to see Pittsburgh, Pennsylvania, returned to India to found Tata Iron and Steel. After years of searching for an ideal location, Jamshedpur was founded (much like Walt Disney World) in a largely uninhabited wilderness area. Tata wrote to his son about designing the town:

Be sure to lay wide streets planted with shady trees, every other of a quick growing variety. Be sure that there is plenty of space for lawns and gardens. Reserve large areas for football, hockey and parks. Earmark areas for Hindu temples, Mohammedan mosques and Christian churches. ${ }^{21}$

Tata's purpose was both humanitarian and shrewd. Disney needed infrastructure (including entertainment attractions) to attract visitors; Tata Steel needed infrastructure to attract workers. Jamshedpur prospered as a company town and it is now the largest city (population of 1.3 million) in the state of Jharkhand and the industrial powerhouse of the region. From 1907 to 2004, municipal services including water, sewage, electricity and even education were provided by the Town Division of Tata Steel. As population increased and Jamshedpur grew beyond the bounds of the Tata leasehold, however, infrastructure quality declined, leading to a reorganization in 2003-2004.

In 2003-2004, Jamshedpur Utilities and Services Company Ltd. (hereafter JUSCO), a wholly-owned subsidiary of Tata Steel, was spun off to service the entire Jamshedpur region. Governance in the larger region is complex, but similar in broad outline to that of Disney and Reedy Creek in that Tata employees interact and intertwine with the larger governance structure.

Jamshedpur is widely regarded as having some of the best urban infrastructure in all of India and JUSCO is considered a model provider. Jamshedpur was rated the second best in the country by ORG Marg Nielsen, the worldwide market research firm, on its quality-of-life index in 2008 and in 2010 ranked seventh of 441 cities and towns in India on sanitation and cleanliness by India's Ministry of Urban Development. Water quality, to give one example, is high enough that water is drinkable from the tap - unusual in India. Total water provision is well above the Indian average. In 2008 JUSCO was noted as 'one of the most effective water service providers on the Indian subcontinent' at the International Global Water Awards (Chiplunkar et al., 2012).

Power availability in Jamshedpur is 99.42 per cent, the highest in India, and comparable only to Mumbai. In addition to a reliable supply of electricity, Jamshedpur has lower tariffs than other cities (Chattoraj, 2006). The leasehold area of Jamshedpur remains the sole city in India where 100 per cent of the sewage is collected and treated before disposal. 
Contrasting Jamshedpur with Gurgaon, Sridhar and Verma (2013) argue that Indian cities such as Gurgaon are dysfunctional because they are typically characterized by conflicts between multiple agencies on who should provide roads, parks, water pipelines, and sewage, and no one seems to have the answer, with authorities passing the buck all the time. Jamshedpur, on the other hand, has succeeded, because through Tata Steel it began with a single owner, and now with the creation of JUSCO, the city has a single provider with encompassing interests and accountability. The result is the provision of integrated and co-ordinated world-class utility services, including water supply, power supply, waste management, and civic services. ${ }^{22}$

\section{Other Private Developments in India}

Lavasa is another privately planned city being built by the Hindustan Construction Company (HCC), one of India's largest builders, in the state of Maharashtra. Lavasa is a private hill city of about 100 square kilometres located outside the city of Pune. Still in development, Lavasa will have five small townships, developed for residential, commercial, and non-polluting industrial uses. The master plan is built around the idea of sustainable urban living. The development of Lavasa was delayed by a few years due to regulatory hurdles imposed by the Ministry of Environment, but the city will soon provide an alternative to cities like Pune.

Another example is the 43-acre Infosys Campus at Electronic City in Bangalore. It is a self-contained city for its 20,000 workers, and contains shops, hotels, restaurants, health club, and a golf course. The campus is well maintained and landscaped and provides its own roads, sewage, water, electricity, garbage disposal, and free bicycles for transport within the campus. Infosys campus is an excellent example of private developers providing various public goods and civic services up to the edge of the property. Those outside the campus cannot enjoy the benefits of these services. One of India's most globally successful firms, Infosys has replicated the Bangalore campus in Pune, Mangalore, and Mysore.

Indian and multinational firms setting up in India are replicating these campuses to provide relevant and reliable infrastructure that is either entirely missing in Indian cities or inadequately provided by the state. 


\section{LESSONS FOR FUTURE CITIES}

How can we build on the examples of Walt Disney World and Jamshedpur? Walt Disney World is some 100 square kilometres in size (not fully urbanized) and it is a large enough city to internalize most externalities and to take advantage of most of the economies of scale necessary to reduce costs to optimal levels. The Tata leasehold area of Jamshedpur is smaller - about 39 square kilometres - while the larger city is some 150 square kilometres, but all of it is much more urbanized than Walt Disney World. Gurgaon is 730 square kilometres (not fully urbanized). Thus there is room in Gurgaon for seven Walt Disney Worlds or, say, five Jamshedpurs.

If the rights to develop Gurgaon had originally been sold in very large packages, some five to seven proprietary but competitive cities could have been created in that region. Within this system the role of the state is to make it possible to auction large parcels of land. Once such parcels and associated rights to develop the land are created, private developers will provision public goods and services up to the edge of their property.

As proprietary communities, the competitive cities would have every incentive to invest in and especially to plan for appropriate infrastructure. Moreover, with five to seven communities in the same region, competitive pressures would keep rents low and at efficient levels for maximizing net benefits (Buchanan and Goetz, 1972; Sonstelie and Portney, 1978). Within the larger city, subdivisions on the order of neighbourhoods and business districts could be sublet and run by competitive firms with the overarching city establishing rules to internalize externalities. Competitive private governments would also generate experimentation and innovation in new rules that would then spread through intercity learning (Romer, 2010). Infrastructure could be fully internalized by each city but with five to seven bargainers, transaction costs would likely be low enough to support joint projects, including control of inter-city externalities. It would also be possible for cities to contract out very large projects - say, electricity - to other cities or to private firms. ${ }^{23}$

It appears that selling very large packages of rights would have been within the feasible set. Creating such a system would not have required much more power than the Chief Minister's Office in Haryana needed to establish Gurgaon and would have required less post-development provision of infrastructure. Walt Disney World and Jamshedpur illustrate in two very different times and locations that such a system is conceivable and attractive. 


\section{CONCLUSIONS}

When the restrictions on land acquisition and development were lifted in Gurgaon, developers responded with tremendous productivity to build private goods such as residences, offices, factories, stores, golf courses, and entertainment complexes. Private services too were provided in abundant quality and a new elite of middle-class Indian workers flocked to Gurgaon to enjoy a modern style of living. Gurgaon, however, like much of India, lacked a government that was willing and able to keep up with private development by building public infrastructure for the delivery of water, sewage, and electricity, and for law enforcement and fire prevention.

Private developers responded with initiative to the lack of public infrastructure in all these areas; compared to the Indian average the net result has been good but not great. The public sector neither built infrastructure nor established a plan with set-asides and rights of way for future infrastructure. Private developers did not build large, cross-property infrastructure projects to take advantage of economies of scale. A failure of regulatory enforcement has also allowed firms to maximize profits by treating common areas as a dumping ground, literally in the case of sewage and figuratively in the case of air pollution and groundwater depletion.

Private developers did, however, build infrastructure up to the property line. Thus, one way to generate more infrastructure and planning is to lower transaction costs by extending the property line. Walt Disney World and Jamshedpur demonstrate that private developers will internalize externalities and plan and build infrastructure projects capable of exploiting economies of scale if the property line extends to the size of a city.

The world's urban population is increasing dramatically. In the next five decades many entirely new cities with populations in the millions will be built in places where today there is little or no population or infrastructure. Most of the urban development will occur in the developing world where government resources are stretched thin and planning is in short supply. Gurgaon illustrates the scope and the limits of private sector provisioning when the state machinery fails to provide essential public goods. The lesson of Gurgaon, Walt Disney World, and Jamshedpur is that a system of proprietary, competitive cities can combine the initiative and drive of private development with the planning and foresight characteristic of the best urban planning. A proprietary city will build infrastructure to attract residents and revenues. A handful of proprietary cities built within a single region would create a competitive system of proprietary cities that build, compete, innovate, and experiment. 


\section{NOTES}

1. Combining estimates from UN World Population Prospects 2010 (mid-range estimate) and UN World Urbanization Prospects 2011.

2. Some of the new cities will be within the administrative districts of old cities.

3. Gurgaon population in 1991. Office of the Registrar General and Census Commissioner (web), Delimitation Commission of India (web), Population Census India (web), 2001.

4. For example, 'Gurgaon now called "India's Singapore",' One India News, September 2, 2008,

http://news.oneindia.in/2008/09/02/gurgaon-the-millennium-city-of-india-1220353969. html.

5. These include the Haryana Apartment Ownership Act (1983), the Haryana Apartment Ownership Rules (1987), the Haryana Ceiling of Land Holdings Act (1972), the Haryana Development and Regulation of Urban Areas Act (1975), the Haryana Industrial Estates (Development and Regulation) Act (1974), the Haryana Municipal Act (1973), the Haryana Municipal Building Bye-Laws (1982) and the Haryana Restrictions on (Development and Regulation of Colonies) Act (1971) (which has been subsequently repealed), the Punjab New Capital (Periphery) Control Act (1952), and the Punjab Scheduled Roads and Controlled Areas Restriction of Unregulated Development Act (1963).

6. The criteria include: a minimum population of 5,000; at least 75 per cent of the male working population should be engaged in non-agricultural pursuits; and a density of population of at least 400 per square kilometre.

7. The absence of an urban local body led to three types of urban development in Gurgaon: first, development projects done by HUDA directly and enabled by the CMO; second, developments by private real estate firms, which were also sanctioned by the CMO; and third, areas controlled by the Haryana State Industrial Development Corporation (HSIDC) for commercial and industrial development. Gurgaon grew into four parts: the old Gurgaon villages (not affected by the bulk of the urban zoning regulation); the HUDA areas, which were mainly for commercial and government use; HSIDC industrial areas; and the commercial and residential enclaves built by private real estate developers.

8. In fact, even office space for the newly elected MCG is yet to be allotted and the power centre in the state capital is refusing to give up control. In December 2012, the government of Haryana transferred the municipal commissioner, the chief engineer, and an executive engineer from the MCG (Joseph, 2012). In addition to wielding power through appointment of officials, the state government is also reluctant to allot the budget of the MCG (Joseph, 2012).

9. Panchayat literally means 'assembly' (ayat) of five (panch) wise and respected elders chosen and accepted by the local community. However, there are different forms of assemblies. Traditionally, these assemblies settled disputes between individuals and villages. Modern Indian government has decentralized several administrative functions to the local level, empowering elected panchayats at the village level.

10. Even residents connected to piped water receive water only a few hours each day due to acute water scarcity. They also rely on private tankers to make up the shortfall.

11. Discussion of crime in Gurgaon is very common among the middle classes. See, for example, http://iamgurgaon.org.

12. A pichkari is an Indian water pistol.

13. The crore is an Indian unit of measure. One crore is 10 million; a thousand crores is ten billion.

14. Many national highways, especially those from Delhi, pass through Gurgaon. These highways are built and maintained by the federal government and National Highway Authority of India (NHAI). Roads within Gurgaon fall within different administrative jurisdictions, including roads built and maintained separately by HUDA, HSIDC, and the MCG. On paper, with the advent of the MCG, all roads built and maintained by 
HUDA and HSIDC should have been transferred to the MCG, as should have private roads and townships, but this has yet to happen. Despite falling under the jurisdiction of the MCG, all privately developed townships, such as DLF City, South City, Sushant Lok (Phase I), and Palam Vihar, continue to be maintained by their respective builders. Private developers continue to build and maintain roads within their areas because the state has not taken over the land, or has simply failed to maintain the roads it has taken over.

15. See Debroy and Bhandari (2009), who report a total paved road length of 1,635 kilometres, using interpolations from various population censuses.

16. http://www.scoopwhoop.com/news/is-the-delhi-gurgaon-toll-road-the-worst-in-theworld.

17. http://www.dlf.in/dlf/wcm/connect/infra/Infrastructure/Infrastructure/Projects/ Infra+Projects/DLF-HUDA+Expressway+Gurgaon/.

18. Tathagata Chatterji laments that over the last 40 years, about a thousand master plans have been prepared for various towns; yet it is difficult to locate a single example where the urban quality of life has improved in terms of better civic facilities (Chatterji, 2003).

19. See http://www.badroadsinindia.com/.

20. Technically, the RCID and WDWC are separate entities, but the RCID Board of Supervisors is elected by landowners on a one-acre, one-vote basis and WDWC owns 98 per cent of all the property in the district.

21. 'History of Tata Steel, 1907-2007' http://www.tatasteel100.com/heritage/history/ history15.asp.

22. See also Sinha and Singh (2011), who argue that Jamshedpur has been successful because private planners always reflected the current thinking of the time and adapted the plan for the changing needs of a growing city. Urban planning in India, on the other hand, is rigid and typically outdated.

23. See, for example, Bish (1971) on contracting out and joint provision in Los Angeles County, which has hundreds of bargaining units, many more than envisioned here.

\section{REFERENCES}

Agan, A. and A. Tabarrok (2005), 'What are private governments worth?' Regulation, 28(3), 14-17.

Ahluwalia, I.J. (2011), Report on Indian Urban Infrastructure and Services. Ministry of Urban Development, Government of India.

Ahuja, S.K. (2010), 'Gurgaon to get fire-fighting bikes,' Hindustan Times, June 10.

Ahuja, S.K. (2013a), 'Gurgaon firms set up 24x7 helplines for women staff,' Hindustan Times, February 6.

Ahuja, S.K. (2013b), 'Highway body failed to deliver on "toll” order,' Hindustan Times, August 19.

Alam, M.T. (2013), 'Power shortage hits industrial production in Gurgaon,' Economic Times, June 1.

Angel, S. (2012), Planet of Cities, Cambridge, MA: Lincoln Institute of Land Policy.

Arnott, R.J. and J.E. Stiglitz (1979), 'Aggregate land rents, expenditure on public goods, and optimal city size,' Quarterly Journal of Economics, 93(4), 471-500.

Beito, D.T., P. Gordon and A. Tabarrok (eds) (2002), The Voluntary City: Choice, Community, and Civil Society, Ann Arbor, MI: University of Michigan Press.

Bish, R.L. (1971), The Public Economy of Metropolitan Areas, Chicago, IL: Markham. 
Buchanan, J.M. and C.J. Goetz (1972), 'Efficiency limits of fiscal mobility: an assessment of the Tiebout model,' Journal of Public Economics, 1(1), 25-43.

Buchanan, J.M. and G. Tullock ([1962] 1999), The Calculus of Consent, Indianapolis, IN: Liberty Fund.

Bureau, F. (2013), 'Revamping Gurgaon's electricity sector,' Friday Gurgaon, February 22.

Chatterji, T. (2003), 'City blights: master plans as masterly failures,' Times of India, September 8.

Chatterji, T. (2013), 'The micro-politics of urban transformation in the context of globalisation: a case study of Gurgaon, India,' South Asia: Journal of South Asian Studies, 32(2), 273-87.

Chattoraj, S. (2006), 'The customer citizen private provisions of civic amenities in Jamshedpur,' Centre for Civil Society Working Paper No. 167.

Chiplunkar, A., S. Kallidaikurichi and C.K. Tan (2012), 'Good practices in urban water management,' Asian Development Bank, National University of Singapore. Available at: http://www.adb.org/publications/ good-practices-urban-water-management.

Chowdhury, T.R. (2009), 'Just 14 fire engines to save 21 lakh, Gurgaon struggles to fight flames,' The Indian Express, April 14.

Coase, R.H. (1959), 'The Federal Communications Commission,' Journal of Law and Economics, 2(October), 1-40.

Coase, R.H. (1960), 'The problem of social cost,' Journal of Law and Economics, 3(October), 1-44.

CSE (2012), Excreta Matters: 71 Cities, New Delhi, India: Centre for Science and Environment.

Dabas, M. (2013), 'Gurgaon's Rapid Metro starts its run on Thursday,' Daily News Analysis: DNA, November 14.

Debroy, B. and L. Bhandari (2009), 'Gurgaon and Faridabad - an exercise in contrasts,' CDDRL Working Paper No. 101, Stanford, CA: Center on Democracy, Development, and The Rule of Law.

Demsetz, H. (1967), 'Toward a theory of property rights,' American Economic Review, 57(2), 347-59.

Dhar, A. (2013), 'Water level depleting, Gurgaon looks to set up its own jal board,' The Indian Express, October 15.

DLF (2012), Press release, June 9.

Foldvary, F.E. (1994), Public Goods and Private Communities: The Market Provision of Social Services, Aldershot, UK: Edward Elgar.

Foldvary, F.E. (1998), 'Municipal public finance,' in F. Thompson and M.T. Green (eds), Handbook of Public Finance, Boca Raton, FL: CRC Press, 397-445.

Foundation for Community Association Research (2013), Statistical Review 2012, FCAR. Available at: http://www.cairf.org/foundationstatsbrochure.pdf.

Gardner, R., N. Gaston and R.T. Masson (2002), 'Tolling the Rhine in 1254: complementary monopoly revisited,' unpublished paper.

Glaeser, E.L. (2008), Cities, Agglomeration, and Spatial Equilibrium, Oxford, UK: Oxford University Press.

Hardin, R. (1978), 'Political requirements for preserving our common heritage,' in H. Bokaw (ed.), Wildlife and America, Washington, DC: Council of Environmental Quality, 310-17.

Harris, G. (2013), 'Rains or not, India is falling short on drinkable water,' The New York Times, March 12. 
Heller, M. (2008), The Gridlock Economy, New York, NY: Basic Books.

Hindustan Times (2013a), 'Crime graph up, Gurgaon police get act together,' Hindustan Times, May 20.

Hindustan Times (2013b), 'Gurgaon to get 50 low-floor AC buses next month,' Hindustan Times, July 27.

Jha, D. (2013), 'Time to privatise power, says Gurgaon,' Hindustan Times, May 13. Joseph, J. (2012), 'Politics behind MCG transfers?' The Times of India, December 5.

Joseph, J. (2013), 'Rapid Metro stations taking shape in Gurgaon,' The Times of India, September 4.

Kane, W. (2013), 'More in Oakland relying on private security,' SF Gate, September 14.

Kumar, A. (2012), 'Court order hailed by Gurgaon citizens but setback for builders,' The Hindu, July 19.

Kumar, K.N. and U. Misra (2012), 'Gurgaon: How not to build a city,' Forbes India, August 2.

MacCallum, S.H. (1970), The Art of Community, Fairfax, VA: Institute of Humane Studies.

MacCallum, S.H. (2002), 'The case for land lease versus subdivision: homeowners' associations reconsidered,' in D. Beito, P. Gordon and A. Tabarrok (eds), The Voluntary City: Choice, Community, and Civil Society, Ann Arbor, MI: University of Michigan Press, 373-406.

McKinsey Global Institute (2010), India's Urban Awakening: Building Inclusive Cities, Sustaining Economic Growth. Available at: http://www.mckinsey.com/ insights/urbanization/urban_awakening_in_india.

Mieszkowski, P. and G.R. Zodrow (1989), 'Taxation and the Tiebout model: the differential effects of head taxes, taxes on land rents, and property taxes,' Journal of Economic Literature, 27(3), 1098-146.

Ministry of Urban Development (2009-2010), 'National Urban Sanitation Policy.' Available at: http://www.urbanindia.nic.in/programme/uwss/slb/SubNUSP. htm.

Morris, S. and A. Pandey (2009), 'Land markets in India: distortions and issues,' in N. Mohanty, R. Sarkar and A. Pandey (eds), India Infrastructure Report 2009: Land - A Critical Resource for Infrastructure, New Delhi, India: Oxford University Press.

National Crime Records Bureau (2012), 'Crime in India 2012.' Available at: ncrb. nic.in/CD-CII2012/Statistics2012.pdf.

Nelson, D. (2011), 'Half of India's cities have no piped water or sewer systems,' Telegraph, October 31.

Ostrom, E. (1990), Governing the Commons: The Evolution of Institutions for Collective Action, New York, NY: Cambridge University Press.

Palit, A. and S. Bhattacharjee (2008), Special Economic Zones in India: Myths and Realities, New Delhi, India: Anthem Press India.

Raina, P. (2012), 'What's behind Gurgaon's power problems?' International New York Times, India Ink, July 4.

Romer, P. (2010), 'Technologies, rules, and progress: the case for charter cities,' Center for Global Development. Available at: http://www.cgdev.org/sites/ default/files/1423916_file_TechnologyRulesProgress_FINAL.pdf.

Scotchmer, S. (2002), 'Local public goods and clubs,' Handbook of Public Economics, 4, 1997-2042. 
Sharma, A., S. Chaturvedi and S. Choudhury (2012), 'India's power network breaks down,' The Wall Street Journal, July 31.

Shleifer, A. and R. Vishny (1992), 'Pervasive shortages under socialism,' RAND Journal of Economics, 23(2), 237-46.

Singh, P.V. (2012), 'Petition: Administrator, HUDA, Gurgaon: make public the information regarding sanitation arrangements in Gurgaon.' Available at: https://www.change.org/en-GB/petitions/administrator-huda-gurgaon-make-pub lic-the-information-regarding-sanitation-arrangements-in-gurgaon.

Singh, R.J. (2013), 'Gurgaon consumes 33.9\% of DHBVN power supply: study,' The Times of India, January 30.

Sinha, A. and J. Singh (2011), 'Jamshedpur: planning an ideal steel city in India,' Journal of Planning History, 10(4), 263-81.

Smith, H. (1976), Consumers: The Art of Queuing, The Russians. New York, NY: Ballantine Books.

Solomon, J. and K. Kranhold (2005), 'In India's outsourcing boom, GE played a starring role,' The Wall Street Journal, March 23.

Sonstelie, J.C. and P.R. Portney (1978), 'Profit maximizing communities and the theory of local public expenditure,' Journal of Urban Economics, 5(2), 263-77.

Sridhar, K.S. and S. Verma (2013), 'A way out of urban chaos,' The Hindu, October 4.

Stringham, E.P. (2009), 'A report on the patrol special police and community safety in San Francisco,' Independent Institute Working Paper No. 74, 1-32.

TNN (2010), 'Badly needed: a decent sewage system for the city,' The Times of India, November 21.

TNN (2013), 'Water table falling rapidly, acute scarcity threatens Gurgaon,' The Times of India, June 24.

TNN (2013a), 'Municipal Corporation of Gurgaon takes over water supply,' The Times of India, October 5.

TNN (2013b), 'Gurgaon to get 21 new bus routes,' The Times of India, September 4.

Yadav, S. (2011), 'Gurgaon cracks whip on 55 security agencies,' Times of India, October 4.

Yadav, S. (2012), 'India's millennium city Gurgaon a "slum for the rich"?' $B B C$ News, August 16.

Yardley, J. (2011), 'In India, dynamism wrestles with dysfunction,' The New York Times, June 8. 